\title{
Typology of Western Border Regions of Russia by the Level and Specifics of Innovation Security Problems
}

\author{
Vasilisa Valeryevna Gorochnaya \\ Academy of Psychology and Educational Sciences \\ South Federal University \\ Rostov-on-Don, Russia \\ I. Kant Baltic Federal University \\ Kaliningrad, Russia \\ tunduk@hotmail.com
}

\begin{abstract}
The article focuses on the problems of innovation security of western border regions of Russia within the conditions of geo-economic turbulence after 2014. The developed and polycriteria typology is urgent due to purposes of decision-making support of innovation sector after the shift of conditions and the grown need for import substitution. Several interconnected typologies are proposed within the study, basing on several criteria. The research involves both quantitative and qualitative data on 15 western border regions of Russia. The implementation of dynamic approach to study innovation security (previously developed by the author) allowed tracing 11 statistic indicators on all the stages of innovation process. These stages are: the potential of primary conditions for research activities, the sector of patenting, the organizational $R \& D$ activities, the production and consumption of innovations and the final volume and share of innovatively produced goods and services. The assessment is given in static and dynamic extent (including the comparison of 4-year periods before and after 2014). The use of dynamic approach pointed out the changes in grouping regions at each of the consequent stages of innovation process. Some regions are developed at the initial stage; other ones are faster developing in implementation of innovations. Also the study involves qualitative data on innovation clustering and regional strategies (which mark the goals, expectations and view on innovations by regional administrations and communities). The research results in the general complex classification, which reflects the picture of involvement of the regions into innovation process, their main problems and strength.
\end{abstract}

Keywords-innovation security, innovative clusters, Russian Western Borderlands, border regions.

\section{INTRODUCTION}

The issues of innovation security are of a high relevance for regional economy, as the level of technological development directly influences the ability to maintain competitive positions within global territorial competition. The phenomenon of innovation growth in a large extent depends on the effects of cross-territorial (including cross-border) spillovers, informational and investment flows and also human capital exchange. That is why the conditions of limited cross-border interaction cause multiple risks for innovation security, especially one of the border regions. Such situation appears in the conditions of geo-economic turbulence within 'RussiaWest' system and influences the general level of economic security of the Russian borderlands and especially its innovation component, as it is sensitive and poorly resistant to the turbulent dynamics [1]. The effect of broken or modified external contacts also enforces the internal problems of innovation security existed previously in the regions. Taking into account the long-term asymmetry of Russian regions' economic, social, cultural and innovation development [2], as well as the variety of current strategies and attempts to overcome the difficulties of the situation (and also each regional community's vision of the essence of the problems), the developed complex classification and typology is needed for both the analytical purposes and the regional policy and management.

\subsection{RELATED WORK}

The basics of the conceptualizing the category of innovation security and the means for its diagnostics in Russia are founded mostly by the researchers of Ural academic school [3], [4], [5], [6] and also continued within the Baltic school focusing on the Western border regions of Russia in the conditions of coastal attraction and cross-border interaction but without the attempts to provide the systematic classification of specific problems of innovation security and the typology of regions [7], [8]. A number of works accents the differentiation of innovation space in national and regional extent (in the both Russian and world practice), pointing out its dependence on regional innovation policy [9] (including the cohesion policy [10]), cultural diversity [11], cross-border investments [12] other factors. So 
the complex and varied approach for solving the specific regional problems in this sphere is urgent, and some studies point out the need for individualization and the new vector in the innovation policy [13], including the application of 'smart specialization' concept [14].

In Russia some classifications and typologies are given to regional innovation systems [15], [16], as they developed before 2014 (the time point of beginning of geo-economic turbulence). Also there are related classifications built accordingly to the criteria of the development level of innovation and investment infrastructure [17] and the general level of competitiveness of regions, including the innovational one [18]. The experience of studying differentiation of regions on the level of innovation security within the general economic security is represented in application to Ural area regions [19].

The classification is given to regional innovation clusters [20], as the innovation clustering is the issue of high relevance in both Russian and world space [21], [22], [23], [24], and this process' specifics also can mark the problems being specific and typical for some territories. Despite the various level of organizational and institutional formation of innovation clusters in Russia (that causes the various level of their effectiveness [25]) and the variety of approaches to the cluster concept itself and its implementation in Russian regional reality [26], regional innovation clustering does influence the economic development of regions, creating the innovation-likely environment and infrastructure [27] and also can serve as the important indicator of strength and weaknesses of regional innovation security, concentrating them in the territorial and industrial extent.

Also the cross-cluster spillovers take place, as both the innovations and clustering trend can be mutually inducted by two or more industries or economic sectors within a region. That is why the regions of various production profiles and some comparatively higher developed and competitive sectors can be grouped into specific typological units. Our previous studies indentified such effects in the touristic regions [28], coastal ones, that is associated with advanced temps of coastal centers' development and the complex of maritime activities, mostly resistant to the geo-economic turbulence [29], and as well as in regions with developed sector of higher education, that lead to the mutual education-innovation clustering [30]. The same takes place in the cases when the clustering involves the interaction between educational sector and business [31]. But despite the fact that the innovation and related sectors' clustering in Russia after 2014 is caused mostly by the same reason, that is the need for import substitution [32], the differentiation of the possibilities for such clustering and the level of innovation security is identified for the regions of the South-West and North-West (as the latter are more deeply integrated into the European space, up to the least stable exclave Kaliningrad region) [33].

The complexity and multi-level reasons for the diversity in the level of innovation security within the Western Borderlands of Russia being the holistic integrity in the Russian socialeconomic system cause the need to develop the multiple typologies of regions that can become the scheme for applying the differentiated and individual measures of support and regulation.

\subsection{OBJECTIVES, METHODOLOGY AND DATA STRATEGY}

This paper presents the multi-level typology of western border regions of Russia accordingly to the character of risks within the geo-economic turbulent situation and the level of their innovation security, measured in both static and dynamic (cyclic) extent, and also in relation to the qualitative characteristics of innovation development and regional innovation policy. Accordingly, to this purpose, the methodology of the research includes the set of statistic methods developed in our previous research within the dynamic approach and approbated, being applied to Rostov region and Kaliningrad region as the representative regions of the Western Borderlands of Russia [33]. This approach is based on the groups of indicators related to the consequent stages of innovation reproduction cycle and is aimed at identifying disconnections between them as the 'cyclic gaps'. Also it involves the statistic analysis of dynamic series (accounting annual growth rates, dispersion and the variation coefficient) to identify the sustainability of cyclic dynamics and the rate of risks. The data analyzed is represented by the information of official Russian regional statistics [34], the archive depth is 8 years (2010-2018) to give the possibility to account growth rates for the periods 2011-2014 and 2015-2018 (4 year periods before and after the beginning of geo-economic turbulence). The data is collected and accounted on the 15 regions: Murmansk region, Karelia Republic, Leningrad region, Kaliningrad region, Pskov region, Smolensk region, Kursk region, Belgorod region, Voronezh region, Rostov region, Krasnodar region, and also for the period 2014-2018 on the Crimea Republic and Sevastopol.

The qualitative analysis involves the factual information collected by the author in a wide range of official sources on the regional innovation clustering (clusters' and firm groups' websites, the official web portals of regional administrations, ministries and cluster development centres). Also the study takes into account the various positions of regional administrations, business-elites and academic societies and their view of the essence of regional problems in the innovation sector and its relation to the economic system of each region. That is why the regional strategic documents were analyzed to identify both the qualitative reasons for innovation security risks and the 'gaps' between the problems identified within the statistic study and their understanding by the regional elites. The method of typology summarizes the both blocks of quantitative and qualitative data analysis.

\section{QUANTITATIVE BACKGROUND}

\subsection{ASSESSMENT OF CURRENT INNOVATION POTENTIAL}

The assessment of primary conditions for innovation activity allows classifying the western border regions into few groups:

- St. Petersburg, the largest center of science and education, also enforced with the largest financial resources for research and technological activity. 
- Leningrad region in the role of 'satellite' of St. Petersburg, inductively high in the extent of research personnel and expenditures, but much lower in number of research organizations, mostly using the externalities of co-location with the big center.

- Regions with comparatively high development level of academic educational and research sector: Rostov and Voronezh regions, and also Krasnodar region, where financial and human potential involved in research is a bit lower, but the organizational space is much bigger (so, this group of regions performs various proportions of conditions for research activities: the number of researchers or the number of organizational forms of their interaction can play the key role).

- Regions concentrating the smaller part of research potential: Murmansk, Belgorod, Kursk regions, Crimea Republic.

- Regions with the lack of human resource in the research sector: Kaliningrad, Smolensk, Bryansk regions and Karelia Republic.

- Regions concentrating the smallest research potential Pskov region and Sevastopol (Fig. 1, the data on St. Petersburg excluded as it is much higher in scale: 294 research organizations, 750.31 hundred researchers, 124165.2 mill. RUR expenditures on research activities).

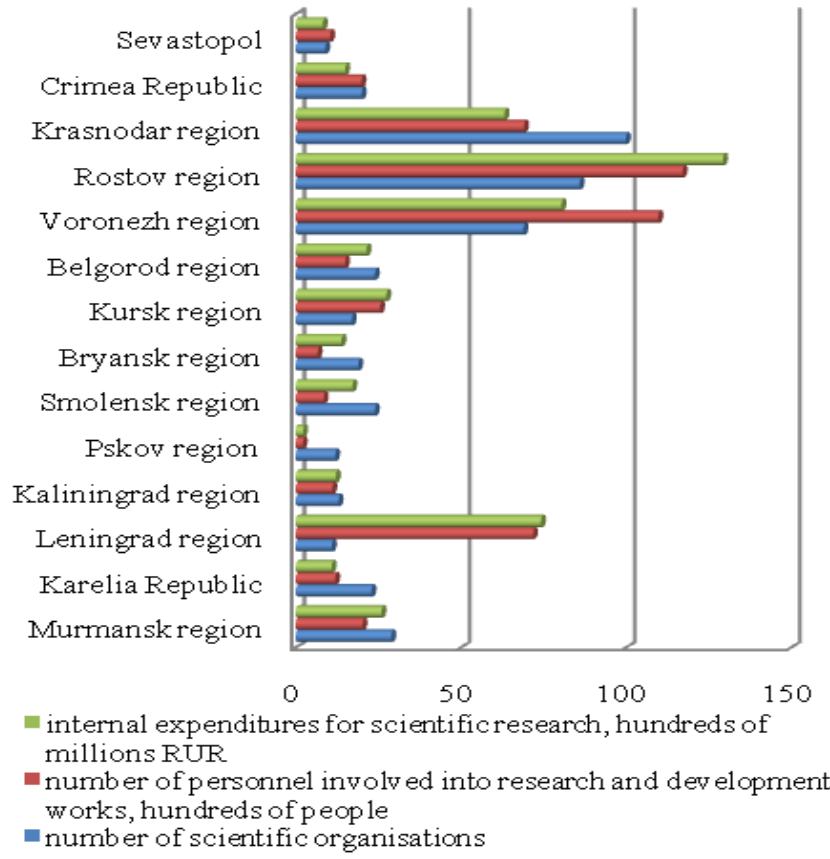

Fig. 1. Primary conditions for innovation activity, 2018

Compiled by author basing on [34]

The data on the second stage of innovation cycle (which is patenting sector) just duplicate the previous stage, but also indicates some details. The regions can be classified into such groups:

- St. Petersburg, applying and registering about 2800-2600 patents per year.
- The regions, where developed research sector induct the patent activity in proportion (Rostov, Voronezh and Krasnodar regions).

- Regions with comparatively higher indicators on patenting in comparison to their range in research potential (Kursk, Belgorod, Bryansk).

- Regions, where smaller research and patenting sectors are just in proportion: Crimea Republic, Karelia Republic, Kaliningrad.

- Regions with smallest patenting sector: Smolensk, Pskov region and Sevastopol.

- Regions with significant disproportion of patenting sector being lower then research one - Murmansk and Leningrad regions (Fig. 2, the data on St. Petersburg excluded as it is much higher in scale).

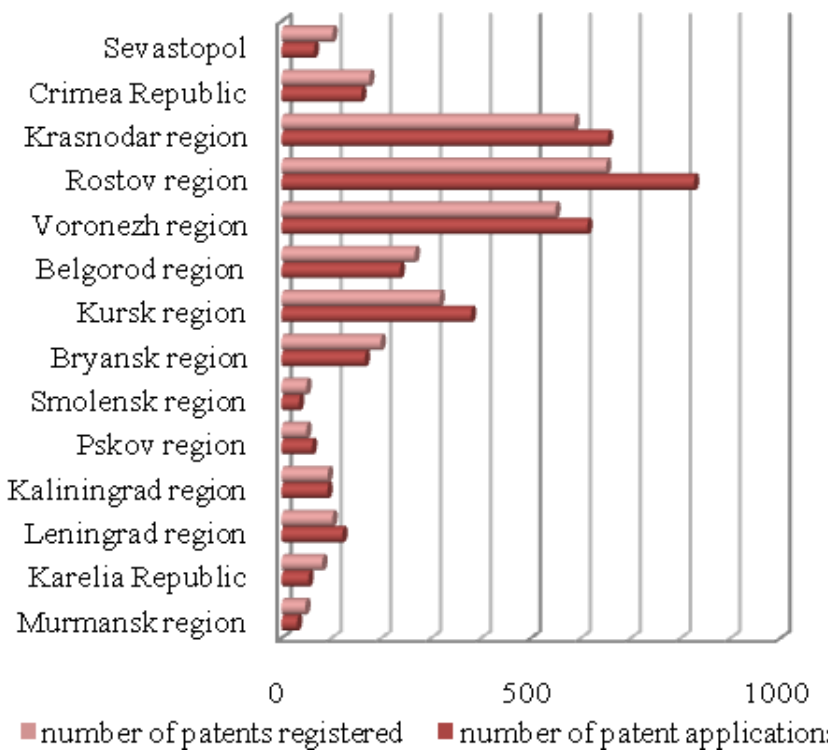

Fig. 2. Patents' applications and registration, 2018

Compiled by author basing on [34]

The stage of the innovative activity by enterprises modifies the previous picture (Fig. 3).

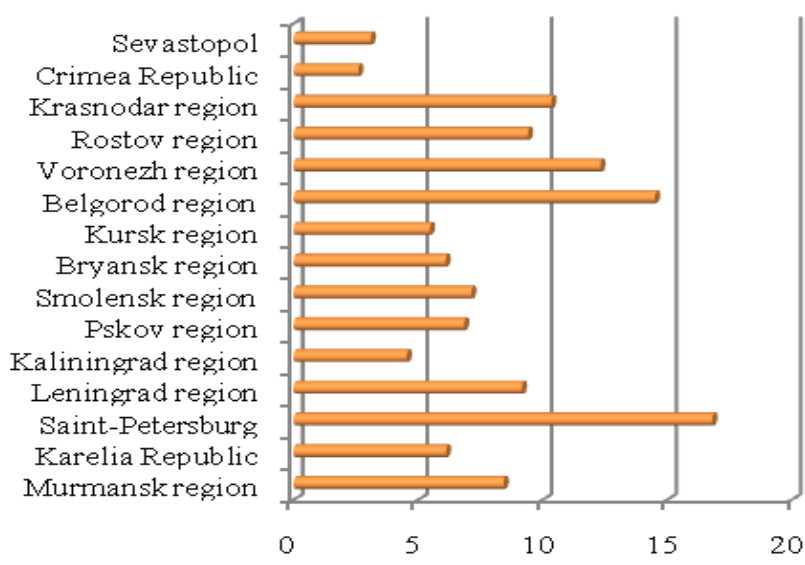

Fig. 3. Share of innovative enterprises, 2018

Compiled by author basing on [34] 
Along with the regions with the big research sector, Belgorod region appears to have the higher percent of innovatively active firms. On the other hand, Rostov region appears to be disproportionally poor active at this stage and occupies just the same position with Murmansk region. The group of regions with the lowest level of this indicator includes Kaliningrad region, Crimea Republic and Sevastopol. The level of expenditures on $\mathrm{R} \& \mathrm{D}$ activities just duplicates the previous picture, except the comparatively higher in Rostov region, that indicates the concentration of innovation activities in the less share of regional enterprises (Fig. 4, the data on St. Petersburg excluded as it is much higher in scale: 94160 mill. RUR).

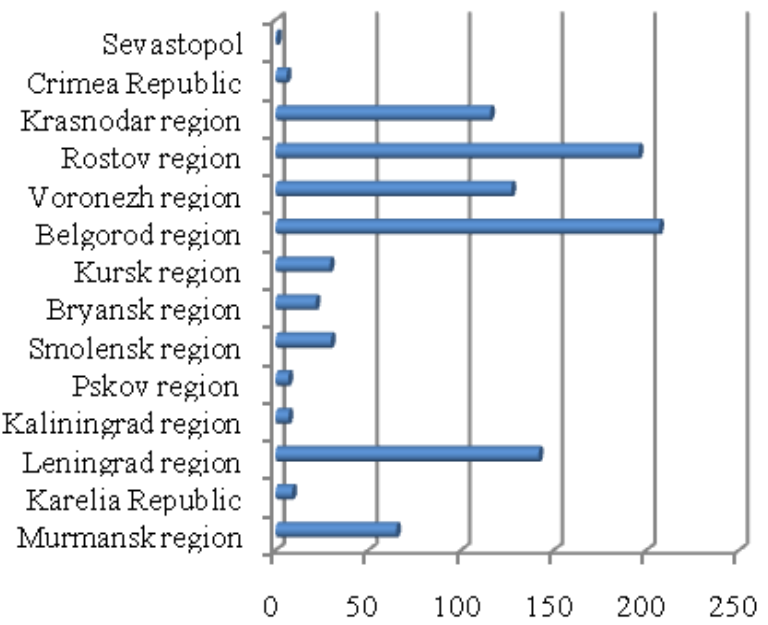

Fig. 4. Expenditures on R\&D, hundred million RUR

\section{Compiled by author basing on [34]}

All the regions act mostly as consumers of technologies, and the level of their production is low, up to extremely low figures and the full absence of producing technologies in some regions (Fig. 5).

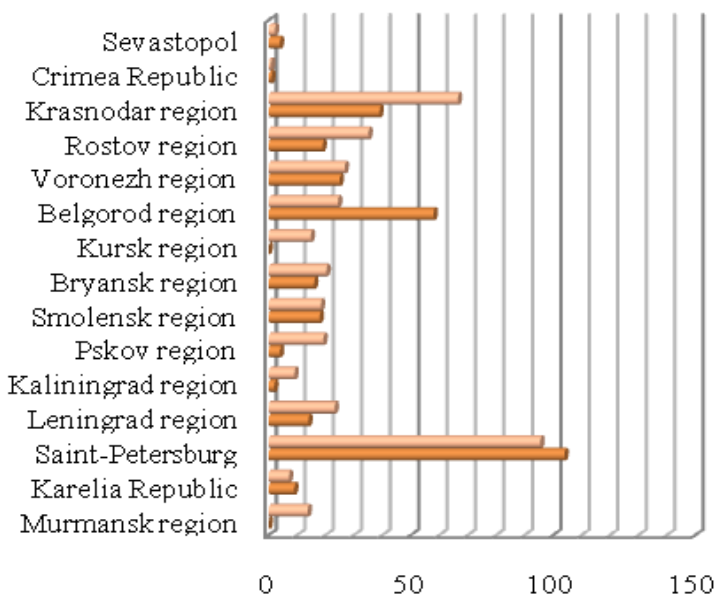

\footnotetext{
number of new technologiesused, hundreds
}

number of technologies produced

Fig. 5. Consumption and production of technologies Compiled by author basing on [34]
Such comparison allows classifying regions into groups:

- Regions, where production of technologies is comparatively higher in proportion to hundreds of technologies in use: St. Petersburg and Belgorod region.

- Regions with comparatively developed production of technologies, but disproportionally staying mostly consumers then inventors: Krasnodar, Voronezh, Rostov, Leningrad, Bryansk and Smolensk regions).

- Regions with the extremely low production of new technologies (Karelia Republic, Crimea Republic, Pskov and Kaliningrad regions).

- Regions with zero production of technologies, as they have lost their previous role in this sector: Kursk and Murmansk regions.

The final stage of innovative process, that is production of goods and services with the use of technologies, also changes some territorial accents (Fig. 6,7).

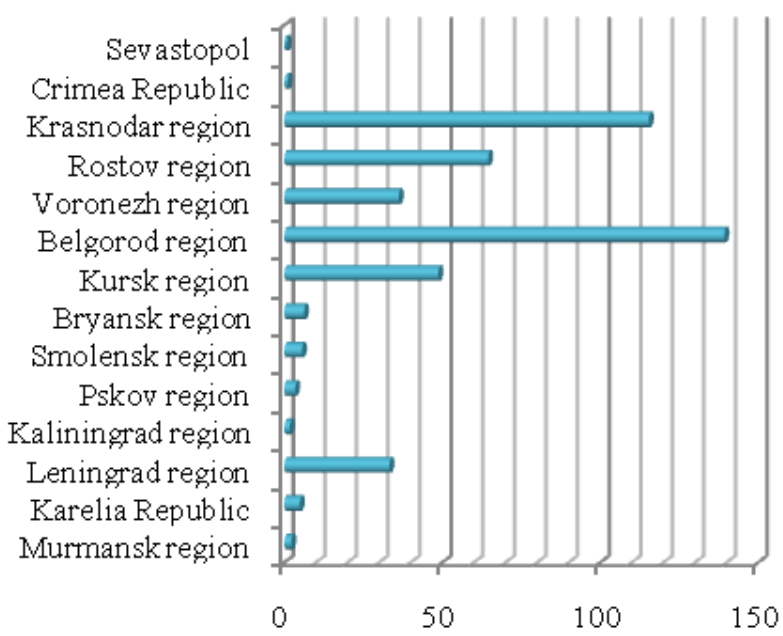

Fig. 6. Volumes of goods and services produced with the use of innovations, thousand million RUR

Compiled by author basing on [34]

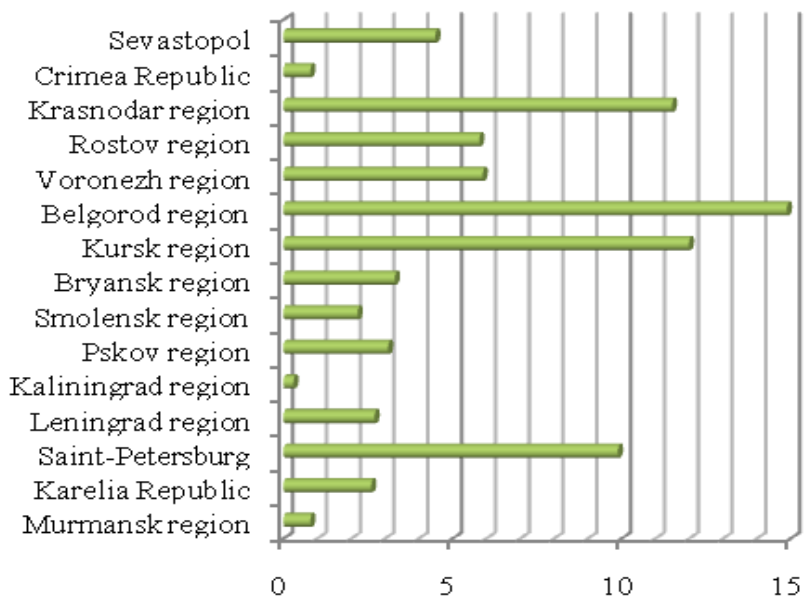

Fig. 7. Share of goods and services produced with the use of innovations in GRP

Compiled by author basing on [34] 
In the absolute figures it indicates the comparatively higher role of Kursk region (as it appears to be a region that does not produce technologies but actively apply them for production), and the comparatively lower role of Voronezh region (as its higher potential at other stages does not fully embody into final productive results).

The comparison to the indicator of the share of innovatively produced goods and services within the GRP allows identifying the groups:

- Regions, where comparatively active involvement into innovative production is significant for the region (about 10$15 \%$ of GRP) - Belgorod and Krasnodar regions.

- Regions, where the share of innovative production does not suite their superior positions in research, patenting and organizational expenditures on $\mathrm{R} \& \mathrm{D}$, because of the presence of large non-innovative sectors within economic structure: St. Petersburg, Rostov, Voronezh and Leningrad regions.

- Regions, in which the share if innovative production in GRP appears quite high at the background of their modest role at other stages - Sevastopol, Kursk and Pskov regions.
- Regions, where their modest role in innovation production does suit the final share of innovative product in GRP - Karelia Republic, Bryansk and Smolensk regions.

- Regions with the extremely low share of innovative production in the GRP structure - Crimea Republic, Kaliningrad and Murmansk regions.

\subsection{DIAGNOSTICS OF INNOVATION DYNAMICS}

The diagnostics of dynamic series for all the mentioned indicators is needed to identify the impact of geo-economic turbulence, that can reflect in both change in trend direction and velocity of impulse spread (fixed by growth rates), and also in the level of instability, the amplitude of oscillation (fixed by the coefficient of variation). As the study shows, the most danger for the whole innovation cycle after the 2014 is the decrease in the number of researchers at the background of slowing growth of financing research work, generating of technologies and the final share of innovative production within GRP, that is reflected in the accounting the indicator for total 13 regions (2011-2014) and 15 regions (2015-2018), Table 1.

\section{TABLE I COMPARATIVE DYNAMICS OF INDICATORS:}

1 - number of scientific organizations, 2 - number of personnel involved into research and development works, 3 - internal expenditures for scientific research, 4 - number of patent applications, 5 - number of patents registered, 6 - share of innovative enterprises, 7 - expenditures on R\&D, 8 - number Compelled by author basing on [34] of technologies produced, 9 - number of new technologies used, 10 - volumes of goods and services produced with the use of innovations, 11 - share of goods and services produced with the use of innovations in GRP

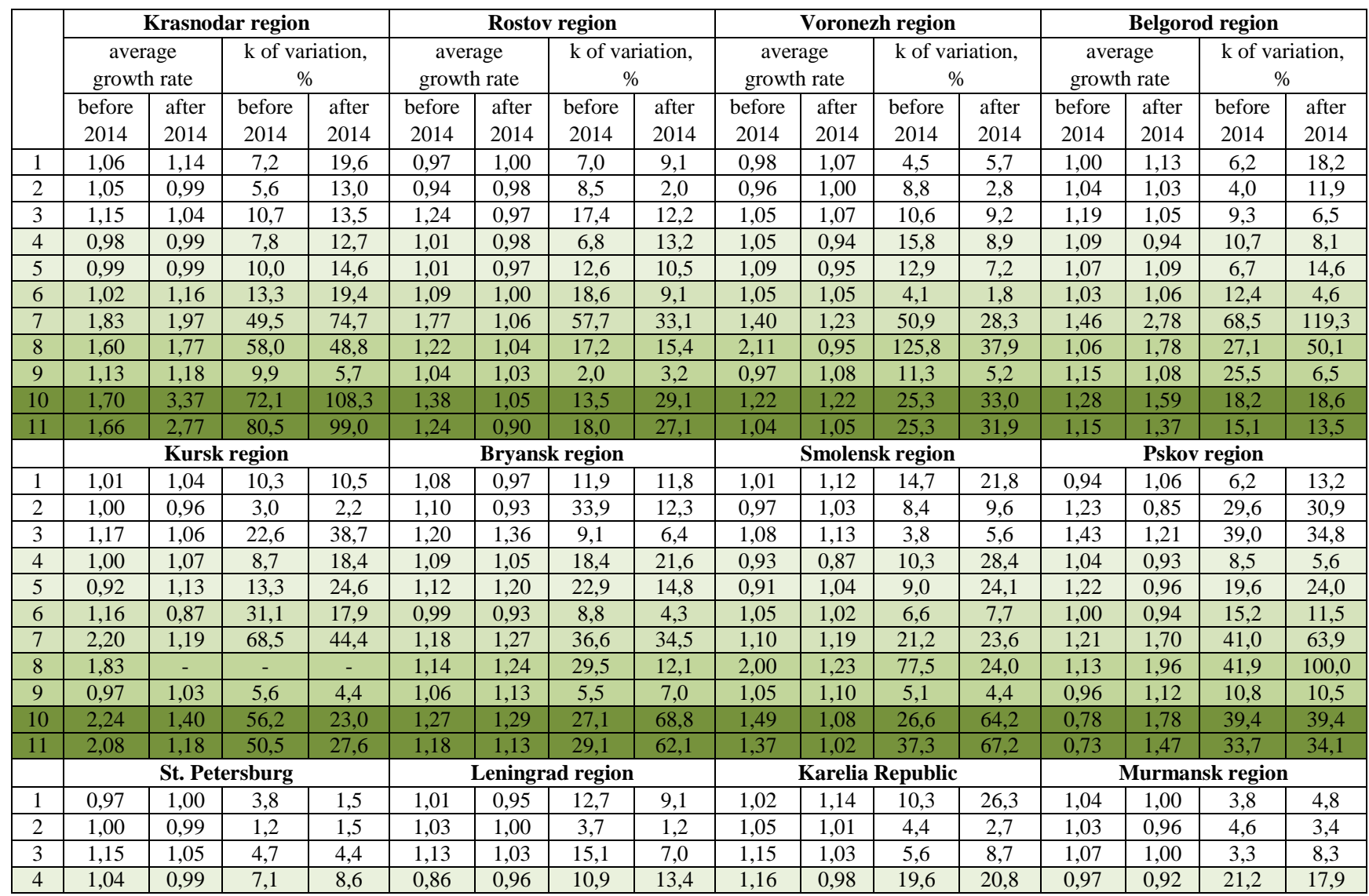




\begin{tabular}{|c|c|c|c|c|c|c|c|c|c|c|c|c|c|c|c|c|}
\hline 5 & 1,03 & 1,04 & 5,1 & 12,1 & 0,91 & 1,07 & 8,2 & 16,4 & 1,23 & 1,11 & 17,7 & 14,4 & 1,05 & 0,97 & 23,4 & 20,1 \\
\hline 6 & 1,11 & 0,98 & 13,2 & 8,7 & 0,99 & 1,02 & 8,8 & 10,7 & 1,07 & 0,95 & 22,0 & 7,6 & 1,05 & 0,96 & 23,0 & 11,9 \\
\hline 7 & 1,41 & 1,08 & 17,5 & 20,0 & 2,41 & 2,08 & 89,8 & 82,2 & 0,42 & 2,50 & 71,4 & 91,9 & 1,19 & 2,09 & 43,3 & 103,3 \\
\hline 8 & 1,19 & 0,83 & 26,2 & 18,0 & 1,20 & 1,10 & 35,0 & 21,4 & 2,82 & 1,01 & 99,6 & 43,6 & - & - & - & - \\
\hline 9 & 1,15 & 1,05 & 5,0 & 5,3 & 1,17 & 1,09 & 12,1 & 8,0 & 0,98 & 1,10 & 31,7 & 5,4 & 1,03 & 1,05 & 18,2 & 7,4 \\
\hline 10 & 1,29 & 1,18 & 27,7 & 6,3 & 1,69 & 1,12 & 63,5 & 26,4 & 0,75 & 3,36 & 63,5 & 109,9 & 3,26 & 0,73 & 132,6 & 63,3 \\
\hline 11 & 1,12 & 0,98 & 11,4 & 14,9 & 1,53 & 0,92 & 64,7 & 25,2 & 0,72 & 3,04 & 61,5 & 118,6 & 3,35 & 0,71 & 142,9 & 65,1 \\
\hline & \multicolumn{4}{|c|}{ Kaliningrad region } & \multicolumn{4}{|c|}{ Crimea Republic } & \multicolumn{4}{|c|}{ Sevastopol } & \multicolumn{4}{|c|}{ Total for $13 / 15$ regions } \\
\hline 1 & 1,03 & 1,04 & 11,7 & 16,4 & - & 1,10 & - & 19,7 & - & 1,30 & - & 42,5 & 1,01 & 1,07 & 8,48 & 15,34 \\
\hline 2 & 1,03 & 0,87 & 8,6 & 12,8 & - & 1,07 & - & 8,9 & - & 1,05 & - & 16,9 & 1,03 & 0,98 & 9,56 & 8,81 \\
\hline 3 & 0,98 & 1,06 & 16,5 & 12,3 & - & 1,41 & - & 35,9 & - & 1,42 & - & 35,4 & 1,15 & 1,13 & 12,90 & 15,93 \\
\hline 4 & 0,94 & 1,05 & 15,5 & 20,9 & - & 1,33 & - & 26,6 & - & 1,47 & - & 51,2 & 1,01 & 1,03 & 12,38 & 18,42 \\
\hline 5 & 1,01 & 1,06 & 13,0 & 19,0 & - & 6,28 & - & 124,3 & - & 1,14 & - & 55,2 & 1,04 & 1,40 & 13,40 & 26,38 \\
\hline 6 & 1,01 & 1,21 & 28,5 & 20,9 & - & 0,76 & - & 39,5 & - & 8,74 & - & 138,8 & 1,05 & 1,51 & 15,82 & 20,95 \\
\hline 7 & 1,30 & 2,19 & 53,7 & 100,7 & - & 1,33 & - & 36,9 & - & 0,90 & - & 67,5 & 1,45 & 1,64 & 51,48 & 61,61 \\
\hline 8 & 2,42 & 1,38 & 109,5 & 32,9 & - & - & - & - & - & 4,00 & - & 0,0 & 1,64 & 1,52 & 58,85 & 33,68 \\
\hline 9 & 0,98 & 1,03 & 9,3 & 3,7 & - & 1,08 & - & 15,4 & - & 1,42 & - & 53,2 & 1,05 & 1,10 & 11,68 & 9,69 \\
\hline 10 & 1,33 & 1,71 & 41,0 & 48,6 & - & 2,14 & - & 69,0 & - & 0,60 & - & 66,7 & 1,51 & 1,58 & 46,68 & 51,64 \\
\hline 11 & 1,21 & 1,75 & 36,6 & 67,6 & - & 1,12 & - & 33,5 & - & 0,43 & - & 72,8 & 1,41 & 1,32 & 46,66 & 50,68 \\
\hline
\end{tabular}

This picture has individually reflected in each region, so taking into account the data in the Tab. 1 and also the results of the trend analysis, it allows identifying several groups:

- Generally 'innovative' regions that firstly actively reacted the situation of geo-economic turbulence growing their innovation sector, but afterwards this impetus was slowing and caused the final reduce of the innovation sector at the most of its stages. These regions are St. Petersburg and Rostov region. But the difference between these 2 regions is the much higher variation in the Rostov region; it also marks the comparatively high level of internal stability (financial, institutional) in St. Petersburg.

- 'Contradictive' regions, which perform general reduce, but reach of maintain high temps of growth in some positions. They are Voronezh and Leningrad regions, still performing growth in expenditures on $R \& D$ and saving the research sector.

- Region that enforced its positions with the active growth dynamics in the most of indicators - Belgorod region.

- Innovation enforcing region, performing turn from research and patenting (as this sector used to be comparatively weak) to the production and use of technologies - Krasnodar region.

- The regions, where growth (mostly in the last, productive stage of innovative process) appears to be significant at the background of low meanings of the most indicators - Karelia Republic, Kaliningrad and Pskov regions. The high level of variation is typical.

- Newly included regions, that adapt to the Russian system of innovation reproduction and institutional conditions Crimea Republic and Sevastopol. They perform mainly high temps of growth, gaining the new wave of investments and included into national programs. But, on the other hand, reduce takes place in some positions, because of destruction of the previously existed patterns and institutional 'gaps'. The extremely high level of variation is typical.

- The 'innovation periphery', where the previous temps of growth of the modest innovation potential are slowing in the new conditions after 2014, along with the growth of instability (Smolensk and Kursk regions) or do not perform any significant changes (Bryansk region), or even there takes place reduce, marking the deepening of periphery positions (Murmansk region)

The common trend is higher oscillation, especially in final volumes of innovative production, the number of technologies produces and the expenditures on $R \& D$.

\section{QUALITATIVE BACKGROUND}

\subsection{INNOVATIVE CLUSTERING}

The analysis of innovation clustering basing on our previous study and inventory of regional clusters within western border regions [35] gives the typology of regions:

1. Ones of early clustering (both industrial and innovation one), where this trend has deep roots in the regional economy. They also subdivide into 2 groups:

1.1 Ones with long-term clustering trend, in which geoeconomic turbulence both stimulated clustering in new importsubstitution sectors and also suffered because of organizational and institutional barriers. Educational and research sector plays the role of integrator for business initiatives. These regions are St. Petersburg and Rostov region.

1.2 Ones that mostly suffered after 2014 as the previously effective clusters (e.g. cross-border ones) were destructed, but the new clusters are projected now in the changed conditions

and with the greater role of state support rather than self-

organization - Kaliningrad region and Sevastopol.

2. Ones that actively involved into clustering after 2014 due to import substitution within innovation sector:

2.1 Voronezh region, where the number of formed clusters and cluster initiatives is high, but not all of them still exist successfully.

2.2 Ones with several sectors and territories involved into innovative clustering as the internal potential is limited (Belgorod, Kursk, Smolensk, Pskov regions).

2.3 Leningrad region as the area of late clustering (began only after 2017), inducted by the 'gravitation' to St. Petersburg, so that some clusters are cross-regional. 
3. Ones, where clustering trend started in recreational sector and is now coming to innovation industries (the most of clusters are projected or at the first stages of embodying) [28]. This process is:

3.1 More active - Krasnodar region and Crimea Republic,

3.2 Less active, slow and more formal - Karelia Republic, Murmansk and Bryansk regions.

\subsection{REGIONAL STRATEGIES}

The overview of regional strategic documents and corresponding analytical papers points out all the regions view innovating to be the means of overcoming internal and external difficulties. But mostly this thesis stays without particular algorithms and ways to enforce it. Region strategies can be divided into:

- Innovation-oriented (including clustering) - Crimea Republic, Rostov and Krasnodar regions.

- 'Human-oriented', focusing on human capital and life quality as the aim of innovating process (St. Petersburg, Karelia Republic, Belgorod, Kursk, Bryansk, Smolensk, Pskov, Leningrad, Kaliningrad, Murmansk regions, Sevastopol, Crimea Republic).

- Accenting innovation as the condition of competitiveness and analyzing the problems of innovation growth, including cross-border limitations or naming the particular market niches for regional innovative product (Crimea Republic, Rostov, Krasnodar, Belgorod, Bryansk, Pskov, Kaliningrad regions).

- Focusing on consensus of social and economic interests and using the concept of sustainable development and diversification (Rostov region, Belgorod, Kursk region).

- Accenting the disconnection of the links of innovation process as the main problem, while the potential is high (Voronezh, Bryansk, Pskov region)

- Using the concept of 'digitalizing' of economy and administrative work (St. Petersburg, Kursk, Pskov, Murmansk regions).

- Considering military sector to be the consumer for regional technological product (Bryansk region).

- Postulating the goal of forming special innovation sector (Smolensk region).

- Viewing global innovation changes to be a thread (e.g. for labor market) - Pskov region.

\section{CONCLUSION}

Summarizing all the classifications given, the complex typology of regions can be proposed:

- High developed centres of education, research and clustering, that need the structural and institutional changes to prevent the beginning decline of innovation dynamics - St. Petersburg, Leningrad, Rostov and Voronezh regions.

- Ones in phase of adaptation (Crimea Republic and Sevastopol).

- Ones actively gaining competitive positions, mostly in the sector of innovative production - Krasnodar and Belgorod regions.

- Ones competitive at some stages of innovation process but with modest internal potential and needing cross-regional and cross-border cooperation (Kursk, Kaliningrad, Bryansk regions).

- Ones needing the aid to organize innovation processes and structures (Smolensk, Pskov regions, Karelia Republic).

- 'Periphery' - Murmansk region.

The further development needs the approach based on deepening territorial labour division in the sphere of innovations and all its stages.

\section{ACKNOWLEDGMENT}

The study was funded by RFBR according to the research project No. 19-010-01083 "Problems of Innovation Security and Mechanisms of Cluster Economic Development of the Border Regions of the European Part of Russia".

\section{REFERENCES}

[1] V.V. Gorochnaya. "Turbulence in geo-economics: methodical approach to modeling the impact on the economic dynamics of a border region". Economics of sustainable development, 2018, No. 4 (36) 136-142.

[2] V.L. Baburin, S.P. Zemtsov. "Geography of innovation processes in Russia“. Moscow University Proceedings. 2013, Vol. 5. Geography, No. 5 25-32.

[3] A.I. Tatarkin, A.F. Sukhovei. "Building the innovative economy in the Russian Federation: Problems and prospects“. Innovations, 2007, No. 7, 11-18.

[4] A.V. Bagaryakov. "Innovation security in the regional economic security system“. Regional economy. 2012, No. 2, 302-305.

[5] A.A. Kuklin, A.V. Bagaryakov, N.L. Nikulina, A.I. Boyarskikh. "Methods of diagnostics of innovative security of the region“. Yekaterinburg. 2013. $83 \mathrm{p}$.

[6] A. Sukhovei "The problems of providing innovative security in Russia". Economy of Region, 2014, No. 4, 141-152.

[7] A.S. Mikhaylov, A.A. Mikhaylova, O.V. Savchina. "Innovation security of cross-border innovative milieu“. Entrepreneurship and Sustainability Issues. 2018, vol. 6, No. 2, 754-766.

[8] A.A. Mikhaylova. "Innovative development and economic security of the Western border regions of Russia. National security / nota bene. 2018, No. 4 (57), 57-72.

[9] F. Tödtling, M. Trippl. One size fits all?: Towards a differentiated regional innovation policy approach“. Research policy. 2005, vol. 34, No. 8, 1203 1219

[10] A.S. Mikhaylov, A.A. Mikhaylova. "National cohesion policies and the influence of interregional divergence gap on innovation sustainability". Journal of Advanced Research in Law and Economics. 2017, vol. 8, No. 6 , 1854-1860.

[11] A. Niebuhr. "Migration and innovation: Does cultural diversity matter for regional R\&D activity? "Papers in Regional Science. 2010, vol. 89, No. 3, 563-585.

[12] N. Smith, E. Thomas. "Regional conditions and innovation in Russia: the impact of foreign direct investment and absorptive capacity". Regional Studies. 2017, No. 51 (9). 1412-1428.

[13] L.K. Gurieva "New strategic approach to the innovative development of regions". Scientific almanac of the black sea countries. 2016, No. 2, 1-4.

[14] S. Zemtsov, V. Barinova. "The paradigm changing of regional innovation policy in Russia: From equalization to smart specialization“. Voprosy economiki. 2016, vol. 10. https://doi.org/10.32609/0042-8736-2016-10$65-81$

[15] A. Petruchenya "Regional Innovation Systems in Russia: Towards Typology of Regions and Policy Recommendations“. Lund University. 2013.

[16] N.N. Mikheeva. "Comparative Analysis of Innovative Systems in the Russian Regions“. Spatial Economics. 2014, No. 4, 61-81.

[17] E.V. Sibirskaya, L.V. Oveshnikova, G.A. Sosedov. "Cluster typology of Russian regions based on their innovation and investment infrastructure evaluation“. Actual problems of economy. 2016, No. 7, 231-239.

[18] M.P. Loginov, E.E. Noeva, G.A. Volkovitckaia, A.A. Murinovich, A.I Serebrennikova. "Competitiveness-based Typology of the Russian Regions“. European Research Studies. 2018, vol. 21, 787-796. 
[19] M. S. Pecherkina, N. L. Nikulina. "Threats of economic safety in the constituent entities of the Ural Federal district". Economic analysis: theory and practice. 2017, vol. 16, No. 9 (468), 1616-1634. (In Russ.)

[20] I.M. Ablaev, Classification of the innovation clusters in the regional economy. Mediterranean Journal of Social Sciences, 2015, vol. 6(1S3), 361-364.

[21] Y.B. Mindlin, S.V. Novikov, S.V. Kireev, A.A. Adamenko, O.V. Belitskaya, "Innovative territorial clusters". International Journal of Economics and Financial Issues, 2016, vol. 6(8S).

[22] E.G. Carayannis, D.F. Campbell, S.S. Rehman, "Mode 3 knowledge production: systems and systems theory, clusters and networks". Journal of Innovation and Entrepreneurship, 2016, vol. 5(1), 1-24.

[23] V.V. Mazur, K.A. Barmuta, S.S. Demin, E.A. Tikhomirov, M.A. Bykovskiy, "Innovation clusters: Advantages and disadvantages". International Journal of Economics and financial issues, 2016, vol. 6(1S)

[24] S. Scott, M. Hughes, S. Kraus, "Developing relationships in innovation clusters“. Entrepreneurship \& Regional Development, 2019, vol. 31(1-2), $22-45$.

[25] R. Kozhukhivska, N. Parubok, N. Petrenko, S. Podzihun, I. Udovenko, "Methods of assessment of efficiency of creating regional innovative clusters for dynamic development of economics". Investment management and financial innovations, 2017, vol. 14, No 3, 302-312.

[26] I.M. Ablaev, Innovation clusters in the Russian economy: Economic essence, concepts, approaches“. Procedia Economics and Finance, 2015, vol. 24, 3-12.

[27] I.M. Ablaev, " Innovation clusters and regional development". Academy of Strategic Management Journal, 2018, vol. 17(3), 1-10.

[28] V.V. Gorochnaya, A.S. Mikhailov, A.A. Mikhaylova, A.P. Plotnikova, "Tourism clusters and innovation security: dialectics in the western border regions of Russia“. GeoJournal of Tourism and Geosites, 2020, vol. 28(1), $127-139$.

[29] V.V. Gorochnaya, A.S. Mikhailov, "Innovation security of coastal areas in Western Borderlands of Russia“. International Conference on Politics, Economics and Management (ICPEM 2019). Dr. Dina M. Elshenawi and Dr. Darko B. Vukovic (Eds.), 2019, 201-208.

[30] V.V. Gorochnaya, A.S. Mikhailov, V.A. Kirik, "Education clusters in fostering innovation security: experience of Rostov and Kaliningrad regions in Western Russia“. Advances in Social Science, Education and Humanities Research, 2019, 523-527.

[31] A.E. Karlik, V.V. Platonov, E.A. Iakovleva, S.N. Shirokov, "Experience of cooperation between St. Petersburg universities and industrial enterprises". In 2016 IEEE V Forum Strategic Partnership of Universities and Enterprises of Hi-Tech Branches (Science. Education. Innovations), 2016, 9-11.

[32] V.V. Karpov, V.A. Kovalev, A.A. Korableva, B.G. Khairov, K.A. Lebedev, "Methodical framework of forming territorial innovation clusters based on import substitution mechanism“". Revista Espacios, 2017, vol. $38(58)$.

[33] V.V. Gorochnaya, A.S. Mikhailov, "Regional innovation security: a dynamic approach to new challenges for the western borderland of Russia “. The 13th International Days of Statistics and Economics. Conference Proceedings. Prague; The Technical University of Košice; The Ton Duc Thung University, Ho Chi Minh City, 2019, 425-433.

[34] Rosstat. Regions of Russia. Social-economic Indicators 2019. Official source. URL: https://rosstat.gov.ru/bgd/regl/b19_14p/Main.htm (accessed 29.10.2020).

[35] V.V. Gorochnaya, Clustering and Innovation Security in the Regions of Western Russia: Inventory and Main Development Trends. Regional economy and management: electronic scientific journal. No. 3 (59), 11. 